\title{
O GÊNERO CARTA DO LEITOR EM DIFERENTES SUPORTES: UM ESTUDO SOB A PERSPECTIVA DA ANÁLISE DIALÓGICA DO DISCURSO
}

\author{
The genre reader's letter in different formats: a study under the perspective of dialogic \\ discourse analysis
}

Terezinha da Conceição Costa-Hubes

Pós-doutora pela Universidade Federal de Santa Catarina - UFSC, Professora da Universidade Estadual do Oeste do Paraná - UNIOESTE, Cascavel, Paraná tehubes@gmail.com Rosangela Oro Brocardo Mestranda pela Universidade Estadual do Oeste do Paraná - UNIOESTE, Cascavel, Paraná, rosangela.oro@gmail.com

RESUMO:O objetivo deste artigo é apresentar uma análise descritivo-interpretativa do gênero discursivo carta do leitor, veiculado no suporte impresso e digital. Para isso, a fundamentação teórico-metodológica estará pautada na Análise Dialógica do Discurso (ADD), recorrendo, portanto, aos estudos bakhtinianos para contextualizar a discussão. Sob essa perspectiva, delimitou-se como corpus 15 textos-enunciados do gênero carta do leitor, publicadas na revista Veja, versões impressa e virtual, em resposta ao artigo de Lya Luft. A apresentação dos dados baseou-se no método sociológico de Bakhtin (1926, 2003,2010,2012) a partir do qual focou-se na análise do conteúdo temático, do estilo e da construção composicional das cartas, observando as regularidades do gênero nesse campo da comunicação. Com base nesses conceitos, buscou-se investigar, ainda, suas relações com o suporte e como esses aspectos se materializam. Além de contribuir com o estudo das regularidades deste gênero da esfera jornalística, a pesquisa poderá ser um material para auxiliar o ensino da linguagem no âmbito escolar.

PALAVRAS-CHAVE: Gêneros do discurso; Análise Dialógica do Discurso; Esfera jornalística; Carta do leitor; Suporte.

ABSTRACT: The objective of this article is to present a descriptive-interpretative analysis of the reader's letter discourse genre, propagated in printed support and digital. For this, the theoretical and methodological basis will be based in the Dialogic Discourse Analysis (DDA), using therefore the bakhtinian studies to contextualize the discussion. From this perspective, it was delimited as corpus 15 statements of the reader's letters genre, published in Veja magazine, in print and digital versions, as a reply to the Lya Luft's article. The presentation of the data was based on Bakhtin's sociological method (1926; 2003; 2010; 2012) from which was focused on the analysis of thematic content, style and compositional construction of letters, observing the regularities of the genre in this communication field. Based on these concepts, we sought to investigate also their relations with the support and how theses aspects materialize. Besides contributing to the study of the regularities of this genre of journalistic sphere, the search may be a material to assist the teaching of language in the school ambit.

KEYWORDS: Discourse genres; Dialogic Discourse Analysis; Journalistic sphere; Reader's Letter; Support. 


\section{INTRODUÇ̃̃O}

As mudanças sociais têm interferido diretamente nos usos da linguagem, de modo que estamos vivendo um momento de maior mobilidade e de reconstrução contínua, refletindo diretamente na maneira de organizarmos nossos discursos. Essa mobilização, que reflete também no campo do conhecimento, vem provocando indagações, principalmente na área da Linguística Aplicada (LA) que, preocupada com seu campo de atuação, tem repensado seus objetivos no sentido de ampliar as possibilidades de estudo da linguagem em suas diferentes formas de materialização. Nesse contexto, a LA tem se colocado como um campo investigativo com "uma abordagem mutável, dinâmica para as questões da linguagem em contextos múltiplos, em vez de como um método, uma série de técnicas, ou um corpo fixo de conhecimento" (PENNYCOOK, 2006, p. 68).

Orientados por esse panorama investigativo, os pesquisadores da LA repensaram outros modos de teorizar, possibilitando, conforme Moita Lopes (2006), que a LA se configurasse, de fato, como "uma área de pesquisa aplicada, na qual a investigação é fundamentalmente centrada no contexto aplicado" (MOITA LOPES, 2006, p. 21), onde as pessoas vivem e agem, onde a linguagem verdadeiramente se manifesta influenciada pela vida sociocultural, política e histórica. Logo, investigar a manifestação de um determinado gênero discursivo, motivado por fatores sócio-histórico, político e ideológico que mobilizam sua reconfiguração, inscreve-se como uma pesquisa em LA, já que tem como foco a materialização da linguagem em certo contexto de uso.

Sustentada por esse posicionamento epistemológico, essa pesquisa tem por objetivo apresentar um estudo descritivo-interpretativo do gênero discursivo carta do leitor nos suportes impresso e digital da revista Veja, atentando para suas regularidades, no que se refere a seu conteúdo temático, seu estilo e sua construção composicional, orientada pelo método sociológico bakhtiniano.

Para tanto, inicialmente são examinamos alguns aspectos importantes para o quadro teórico em que a pesquisa se insere, a Análise Dialógica do Discurso (ADD) e a teoria de gêneros do discurso do Círculo de Bakhtin ${ }^{1}$. Após justificarmos a perspectiva teórico-metodológica na qual nos pautamos, procedemos à descrição do corpus selecionado para este estudo para, em seguida, evidenciarmos os horizontes temático-estilístico-composicionais do gênero carta do leitor, apresentando as regularidades observadas no processo de análise. Assim, pautadas em Bakhtin, "Estamos interessados primordialmente nas formas concretas dos textos e nas condições concretas da vida dos textos, na sua inter-relação e interação. [...] A índole metalinguística do enunciado (da produção do discurso).” (BAKHTIN, 2003 p. 319-320)

\footnotetext{
${ }^{1}$ Utiliza-se a expressão Círculo de Bakhtin porque, além do pensador Mikhail Bakhtin, as formulações e as obras são produto de reflexão de um grupo que tinha a participação de outros intelectuais, entre eles V. N. Volochinov e P.N. Medviedev. Para maiores informações acerca do assunto, indicamos a obra Bakhtin $e o$ Círculo, de Beth Brait, editora Contexto, 2009. Não é nosso objetivo entrar no debate a respeito da autoria das obras. As que aqui forem citadas respeitarão as assinaturas presentes nas edições utilizadas.
} 


\section{A CONCEPÇÃO DE TEXTO E DE DISCURSO: RELAÇÕES NA PERSPECTIVA DA ANÁLISE DIALÓGICA DO DISCURSO}

Para falarmos de texto, no sentido de defini-lo teoricamente, precisamos, antes de tudo, colocar-nos no limite teórico no qual nos inscrevemos, já que o termo "texto" tem polarizado discussões advindas de diferentes vertentes teóricas relacionadas à linguagem. Neste estudo, posicionamo-nos no sentido defendido por Bakhtin:

O texto (escrito ou oral) enquanto dado primário de todas essas disciplinas, do pensamento filológico-humanista no geral (inclusive do pensamento teológico e filosófico em sua fonte). O texto é a realidade imediata (realidade do pensamento e das vivências), a única da qual podem provir essas disciplinas e esse pensamento. Onde não há texto não há objeto de pesquisa e pensamento. [...] Independentemente de quais sejam os objetivos de uma pesquisa, só o texto pode ser o ponto de partida. (BAKHTIN, 2003, p. 307308)

É possível depreendermos das palavras do autor que o texto é a mais pura manifestação da linguagem, organizado por um sujeito que, inserido em determinado contexto e atendendo a determinada necessidade de interação, organiza seu discurso que, materializado no texto, revela-se em sua plenitude. Sendo assim, estudar a linguagem significa estudar textos, o ponto de partida de todo processo investigativo ancorado nas manifestações da linguagem. Todavia, como o próprio autor anuncia, "cada texto é algo individual, único e singular, e nisso reside todo o seu sentido" (BAKHTIN, 2003, p. 310). Tendo em vista a plasticidade dos textos, acreditamos que é possível esboçar algumas projeções, centradas na recorrência de alguns preceitos.

Para a realização de um estudo de texto, precisamos considerar, de imediato, seu contexto de produção, uma vez que seu sentido é construído na interação entre sujeitos, a partir de determinado contexto sócio-historicamente situado. A noção de texto, nesse caso, está necessariamente imbricada ao conceito de enunciado não como unidade autônoma, mas ligada a uma rede de outros textos, enunciados, discursos, conforme explica Brait:

Se um determinado texto, um editorial, por exemplo, for recortado do jornal em que apareceu, e se for analisado, interpretado, sem relação com os demais textos que compunham o jornal naquele dia, ou seja, as matérias do dia e/ou anteriores cujas temáticas ajudam a entender esse texto opinativo, a

\footnotetext{
2 "Não se pode negar que o pensamento bakhtiniano representa, hoje, uma das maiores contribuições para os estudos da linguagem, observada tanto em suas manifestações artísticas como na diversidade de riqueza cotidiana. Por essa razão, mesmo consciente de que Bakhtin, Voloshinov, Medvedev e outros participantes do que atualmente se denomina Círculo de Bakhtin jamais tenham postulado um conjunto de preceitos sistematicamente organizados para funcionar como perspectiva teórico-analítica fechada arrisca-se a sustentar que o conjunto das obras do Círculo motivou o nascimento de uma análise/teoria dialógica do discurso, perspectiva cujas influências e consequências são visíveis nos estudos linguísticos e literários e, também, nas Ciências Humanas de maneira geral. Sem querer (e sem poder) estabelecer uma definição fechada do que seria essa análise/teoria dialógica do discurso, uma vez que esse fechamento significaria uma contradição em relação aos termos que a postulam, é possível explicitar seu embasamento constitutivo, ou seja, a indissolúvel relação existente entre línguas, linguagens, história e sujeitos que instaura os estudos da linguagem como lugares de produção de conhecimento de forma comprometida, responsável, e não apenas como procedimento submetido a teorias e metodologias dominantes em determinadas épocas. [...]. As contribuições bakhtinianas para uma teoria/análise dialógica do discurso, sem configurar uma proposta fechada e linearmente organizada, constituem de fato um corpo de conceitos, noções e categorias que especificam a postura dialógica diante do corpus discursivo, da metodologia e do pesquisador". (BRAIT, 2006, p. 9-29, grifo da autora).
} 
postura do jornal, o projeto gráfico em que estava inserido, dentre vários outros aspectos ligados à esfera de produção, circulação e recepção, esse texto não poderá ser considerado bakhtinianamente, isto é, como parte do todo do enunciado concreto, completo. (BRAIT, 2012, p. 19)

Ao estabelecer estas relações entre texto e enunciado, Brait (2012) retoma postulados defendidos por Bakhtin: "Não pode haver enunciado isolado. Ele sempre pressupõe enunciados que o antecedem e o sucedem. Nenhum enunciado pode ser o primeiro ou o último. Ele é apenas o elo na cadeia e fora dessa cadeia não pode ser estudado" (BAKHTIN, 2003 , p. 371). Essa ancoragem enunciativa quer garantir o postulado de texto como forma de enunciação, ou seja, é no texto que o sujeito se manifesta verdadeiramente e é no texto que ele revela as múltiplas vozes que o constitui, pois seu discurso é constituído dialogicamente. "A linguagem só vive na comunicação dialógica daqueles que a usam. É precisamente essa comunicação dialógica que constitui o verdadeiro campo da vida da linguagem. Toda vida da linguagem, qualquer que seja seu campo de emprego, está impregnada de relações dialógicas" (BAKHTIN, 2010, p. 209).

Essa noção de enunciado e sua perspectiva dialógica nos leva, assim, ao conceito bakhtiniano de discurso, que, para o autor, é "a língua em sua integridade concreta e viva" (BAKHTIN, 2010, p. 207), o que significa reconhecer a dialogicidade do discurso que, segundo Bakhtin, "[...] é por natureza dialógico" (BAKHTIN, 2010, p. 209). Sob esse ponto de vista, o discurso não se reduz na materialidade do texto, mas é constituído por suas relações extralinguísticas. Essa constatação se confirma em Brait quando a autora afirma que "a abordagem do discurso não pode se dar somente a partir de um ponto de vista interno ou, ao contrário, se uma perspectiva exclusivamente externa. Excluir um dos polos é destruir o ponto de vista dialógico" (BRAIT, 2012, p. 23). O discurso é construído, assim, tanto na materialidade linguística do texto quanto no contexto extralinguístico no qual ele se configura. É na reenunciação dos já ditos que o texto/discurso ${ }^{3}$ se revela em toda a sua plenitude, ancorado por marcas enunciativas do sujeito que, ao posicionar-se axiologicamente, constrói o seu texto/discurso. Todo texto/discurso pressupõe uma autoria: "Todo enunciado tem um espécie de autor que no próprio enunciado escutamos como o seu criador. Podemos não saber absolutamente nada sobre o autor real, mas ele existe fora do enunciado. As formas de autoria desse enunciado podem ser muito diversas" (BAKHTIN, 2010, p. 210). E, da mesma forma, todo texto/discurso demanda um interlocutor, é para ele que construímos o texto/discurso e é em função dele que o organizamos. Assim, no texto/discurso, "toda palavra presente responde e reage com todas as suas fibras ao interlocutor [...] a palavra do outro influencia ativamente o discurso do autor, forçando-o a mudar sob o efeito de sua influência e envolvimento" (BAKHTIN, 2010, p. 226).

Ao observamos esses aspectos que se estabelecem dialogicamente, entendemos que texto/discurso são conceitos que se imbricam, o que significa dizer que, ao tomar um texto como objeto de estudo, essa prática exige muito mais que uma análise puramente linguística, pois pressupõe compreendê-lo e estudá-lo em toda a sua plenitude, considerando desde seu

\footnotetext{
${ }^{3} \mathrm{Na}$ perspectiva bakhtiniana os conceitos de texto e de discurso se interligam, se interdependem e apontam para uma maneira particular de entender a linguagem. Segundo Brait, “[...]o conceito de texto produzido pelos trabalhos de Bakhtin/Voloshinov afasta-se de uma concepção que o colocaria como autônomo, passível de ser compreendido somente pelos elementos linguísticos, por exemplo, ou pelas partes que o integram, para inseri-lo numa perspectiva mais ampla, ligada ao enunciado concreto que o abriga, a discursos que o constituem, a autoria individual ou coletiva, a destinatários próximos, reais ou imaginados, a esferas de produção, circulação e recepção, interação." (BRAIT, 2012, p. 10, grifo da autora)
} 
complexo semântico, até seu contexto sócio-histórico e ideológico em que as marcas da interação se configuram.

Estudar a linguagem significa, nessa perspectiva, ir além da análise das estruturas verbais, das formas da língua, direcionando o olhar para o(s) sentido(s) do discurso produzido numa situação única de enunciação, procurando desvendar as relações dialógicas que ali se estabelecem, entendendo que elas são possíveis entre "qualquer parte significante do enunciado, inclusive a uma palavra isolada, caso essa não seja interpretada como palavra impessoal da língua, mas como signo da posição semântica de um outro, como representantes do enunciado de um outro, ou seja, se ouvimos nela a voz do outro" (BAKHTIN, 2010, p. 210). As relações dialógicas estão presentes em todos os textos/discursos, uma vez que construímos nossos enunciados a partir das vicissitudes de discursos engendrados, com os quais dialogamos constantemente. Nesse sentido, conforme Brait,

[...] o dialogismo diz respeito ao permanente diálogo, nem sempre simétrico e harmonioso, existente entre os diferentes discursos que configuram uma comunidade, uma cultura, uma sociedade. É nesse sentido que podemos interpretar o dialogismo como o elemento que instaura a constitutiva natureza interdiscursiva da linguagem. Por um outro lado, o dialogismo diz respeito às relações que se estabelecem entre o eu e o outro nos processos discursivos instaurados historicamente pelos sujeitos, que por sua vez, instauram-se e são instaurados por esses discursos. (BRAIT, 2007 p. 69)

Sob esse ângulo, numa perspectiva de análise de texto/discurso, precisamos partir do princípio de que "o enunciado é pleno de tonalidades dialógicas, e sem levá-las em conta é impossível entender até o fim o estilo de um enunciado" (BAKHTIN, 2003, p. 298). Estudar um texto significa tomá-lo a partir de seu contexto real, o que pressupõe reconhecer seu momento histórico de produção, um autor sócio-historicamente definido, interlocutor(es) idealizados, um suporte que o sustente e um veículo que permita a sua circulação. Tomando esses elementos como referência e considerando o conteúdo temático que o configura, assim como o estilo presente em sua organização, configurada em determinado gênero do discurso, para atender a um fim específico, é possível estabelecer com o texto um diálogo.

Assim, entendemos que os textos podem ser compreendidos como a materialidade do discurso de determinada esfera da atividade humana que, para fazer-se presente socialmente, elabora seus enunciados de maneira "relativamente estável" (BAKHTIN, 2003, p. 283), os gêneros do discurso. Nesse sentido, para o verdadeiro domínio da linguagem, o reconhecimento de um gênero se constitui como algo essencial, uma vez que todas as situações comunicativas só se efetivam por meio de enunciados concretos materializados nos gêneros discursivos.

Partindo do princípio de que todas as esferas da atividade humana estão sempre relacionadas com a utilização da linguagem, constituindo-se como princípio básico da interação verbal, então, concordamos com Faraco:

Se queremos estudar o dizer, temos sempre que nos remeter a uma ou outra esfera da atividade humana, porque não falamos no vazio, não produzimos enunciados fora das múltiplas e variadas esferas do agir humano. Nossos enunciados (orais ou escritos) têm, ao contrário, conteúdo temático, organização composicional e estilo próprios correlacionados às condições específicas e às finalidades de cada esfera de atividade. (FARACO, 2009, p. 126) 
Tendo em vista que novos gêneros surgem (ou se modificam) a partir de novas exigências de interação por meio da linguagem, torna-se, assim, objeto de estudo relevante a ação da linguagem, em sua função como mediadora das práticas sociais, no que se refere à análise da produção, compreensão, interpretação desses tipos de enunciados, pois, conforme Bakhtin,

O estudo da natureza do enunciado e da diversidade de formas de gênero dos enunciados nos diversos campos da atividade humana é de enorme importância para quase todos os campos da linguística.[...] O desconhecimento da natureza do enunciado e a relação diferente com as peculiaridades das diversidades de gênero do discurso em qualquer campo da investigação científica redundam em formalismo e em uma abstração exagerada, deformam a historicidade da investigação, debilitam as relações da língua com a vida. (BAKHTIN, 2003, p. 264-265)

Ao estudarmos a natureza do enunciado e ao considerarmos que, para Bakhtin, os gêneros discursivos são "relativamente estáveis", entendemos que é preciso considerar a historicidade dos gêneros, sua mudança, pois, à medida que as esferas de atividade se desenvolvem, gêneros desaparecem, aparecem, diferenciam-se, ganham novos sentidos. Assim, a análise de discursos não fica reduzida à sua forma de composição, ao estilo e ao conteúdo temático, mas vai além da situação imediata de interlocução, ao buscarmos indícios de sua heterogeneidade constitutiva, sua participação em esferas de produção, as quais lhes conferem efetiva atuação. Nesse sentido, Rodrigues afirma:

Os gêneros, com seus propósitos discursivos, não são indiferentes às características de sua esfera, ou melhor, eles as "mostram". Todo gênero tem um conteúdo temático determinado: seu objeto discursivo e finalidade discursiva, sua orientação de sentido específica para com ele e os outros participantes da interação. (RODRIGUES, 2007, p. 167, grifo da autora)

Interessante observar que, ao mesmo tempo em que estudamos os gêneros discursivos, notamos que estes se reconfiguram, uma vez que se são capazes de responder ao novo. Faraco, nesse sentido, afirma que "o repertório de gêneros de cada esfera da atividade humana vai diferenciando-se e ampliando-se à medida que a própria esfera se desenvolve e fica mais complexa" (FARACO, 2009, p. 127).

Entendemos, assim, que é somente nessa situação de interação, ao relacionarmos o gênero e sua esfera de atividade e comunicação humana, que se pode apreender a constituição e o funcionamento dos gêneros. Sob a perspectiva da Análise Dialógica do Discurso, os gêneros se desenvolvem de acordo com as esferas, apresentando características peculiares, influenciados pelas especificidades de cada esfera. Tendo em vista que, para Bakhtin (2003) os gêneros são compreendidos como enunciados que se estabilizam nas diversas situações de interação, essas esferas sociais, por conseguinte, se mostram como princípios organizadores das formas de interação verbal.

Ao tratarmos do gênero carta do leitor, o qual está inserido no meio jornalístico, entendemos que esta esfera influencia em sua organização, funcionamento e circulação, conforme AcostaPereira comenta:

[...] a esfera social do jornalismo desencadeia reações ideológicas intimamente relacionadas às condições sociais e aos valores sociais atribuídos aos gêneros que nesse campo circulam. Dessa forma, as diferentes 
situações de comunicação verbal que se produzem e circulam na esfera do jornalismo são revestidas de ideologias e valorações. (ACOSTA-PEREIRA, 2008, p. 69).

Nesse sentido, acreditamos que cada esfera organiza suas formas típicas de comunicação social, à medida que, conforme Bakhtin:

As relações de produção e a estrutura sociopolítica que delas diretamente deriva determinam todos os contatos verbais possíveis entre indivíduos, todas as formas e os meios de comunicação verbal: no trabalho, na vida política, na criação ideológica. Por sua vez, das condições, formas e tipos da comunicação verbal derivam tanto as formas como os temas dos atos de fala. (BAKHTIN, 2012, p. 43).

Compreendemos, assim, que é impossível estudar um gênero sem considerar sua esfera de produção, uma vez que esta orienta para o que e como dizer.

\section{A QUESTÃO DO SUPORTE}

As discussões sobre a influência (ou não) do suporte na constituição dos gêneros ainda é uma área em andamento. Segundo Marcuschi (2003; 2008), ainda há necessidade de estudos mais sistemáticos a respeito do suporte dos gêneros textuais/discursivos. Mesmo assim, este autor esclarece que:

A ideia central é que o suporte não é neutro e o gênero não fica indiferente a ele. [...] Ele é imprescindível para que o gênero circule na sociedade e deve ter alguma influência na natureza do gênero suportado. [...] Entendemos aqui como suporte de um gênero um lócus físico ou virtual com formato específico que serve de base ou ambiente de fixação do gênero materializado como texto. (MARCUSCHI, 2008, p. 174)

Já para Bonini (2011), dentre os estudos sobre a relação entre suporte e o gênero, pode-se apontar três trabalhos que discutem a questão (MARCUSCHI, 2003; BONINI, 2003; TÁVORA, 2008), porém, nenhum considerou a mídia ${ }^{4}$ como fator relevante, aspecto que para o autor, pode colaborar como forma de resolver alguns problemas conceituais. Assumimos, assim, neste trabalho os conceitos relacionados entre mídia e suporte propostos por Bonini:

a) mídia - tecnologia de mediação da interação linguageira e, portanto, do gênero como unidade dessa interação. Cada mídia como tecnologia de mediação, pode ser identificada pelo modo como caracteristicamente é organizada, produzida e recebida e pelos suportes que a constituem; e

b) suporte - elemento material (de registro, armazenamento e transmissão de informação) que intervém na concretização dos três aspectos caracterizadores de uma mídia (suas formas de organização, produção e recepção). (BONINI, 2011, p. 688)

\footnotetext{
${ }^{4}$ Segundo Bonini (2011), a respeito da relação entre suporte e mídia, Debray (1993) esboça uma tentativa de abordagem, o qual assim se pronuncia: "Ainda que nos limitemos exclusivamente à comunicação verbal, simbólica e não indicial, aquela que, portanto, exige colocação em código e decodificação, o termo médium poderá aplicar-se tanto à linguagem natural utilizada (inglês ou latim), como ao órgão físico de emissão e apreensão (voz que articula, mão que traça sinais, olho que decifra o texto), ao suporte material dos traços (papel ou tela), ao processo técnico de coleta de dados e reprodução (impresso, eletrônico): ou seja, no mínimo quatro acepções" (grifos do autor)
} 
Entendemos que, tanto em sua versão impressa, quanto em sua versão online, as cartas do leitor publicadas na revista Veja acabam por serem influenciadas em sua constituição geral, ao terem seus projetos de dizer reacentuados de acordo com cada suporte e mídias em que circulam. Isto se mostra coerente com o pensamento bakhtiniano o qual considera que "as formas de interação verbal acham-se muito estreitamente vinculadas às condições de uma situação social dada e reagem de maneira muito sensível a todas as flutuações da atmosfera social.” (BAKHTIN, 2012, p. 43)

$\mathrm{Na}$ perspectiva de relacionar essas reflexões teóricas com o corpus, explicitamos, na sequência, o percurso metodológico que adotamos para, em seguida, realizarmos a análise.

\section{PERCURSO METODOLÓGICO E APRESENTAÇÃO DOS DADOS}

Neste artigo, apresentamos uma descrição interpretativa da constituição e do funcionamento do gênero discursivo carta do leitor, da esfera jornalística. Os referenciais teóricometodológicos estão pautados no método sociológico e na Análise Dialógica do Discurso (ADD) do Círculo de Bakhtin. Buscamos, com isso, identificar as regularidades enunciativodiscursivas que permeiam o gênero carta do leitor em diferentes suportes, procurando analisar sua relativa estabilização.

Ao procedermos a uma análise linguística dos recursos mobilizados pelo locutor no gênero discursivo carta do leitor, cabe ressaltar que não pretendemos nos restringir unicamente à análise das palavras que formam as estruturas textuais, mas buscamos explicitar os sentidos produzidos pelo enunciador ao proceder à seleção das palavras nesse contexto discursivo, isto é, a relação entre o texto e a situação comunicativa na qual este se insere. Para isso, conforme prevê Bakhtin, torna-se imprescindível que a ordem metodológica para o estudo da língua seja seguida, as quais consistem em considerar:

1) As formas e os tipos de interação verbal em ligação com as condições concretas em que se realiza;

2) As formas das distintas enunciações, dos atos de fala isolados, em ligação estreita com a interação de que constituem os elementos, isto é, as categorias e atos de fala na vida e na criação ideológica que se prestam a uma determinação pela interação verbal;

3) A partir daí, exame das formas da língua na sua interpretação linguística habitual. (BAKHTIN, 2012, p. 129)

Considerar o método sociológico significa: 1) estudar a língua relacionando-a às formas e aos tipos de interação verbal, ligando-a com as condições concretas em que se realiza, ou seja, ao seu contexto de produção; 2) elucidar as formas distintas de enunciações e sua ligação estreita com as condições em que se realiza; 3) examinar as formas da língua dentro desse contexto de interação. Tal orientação metodológica foi retomada, posteriormente, por Bakhtin (2003), em Estética da Criação Verbal, quando defende que os campos da atividade humana (esferas sociais) estão ligados pela linguagem que se revela de maneira multiforme. Assim, a língua torna-se viva, dinâmica e concreta nos enunciados proferidos pelos integrantes de cada esfera. Portanto, para estudá-la, é preciso estudar os enunciados nos quais a língua (palavra) se realiza, pois,

Esses enunciados refletem as condições específicas e as finalidades de cada referido campo não só por seu conteúdo (temático) e pelo estilo da linguagem, ou seja, pelos recursos lexicais, fraseológicos e gramaticais da 
língua mas, sobretudo, por sua construção composicional. Todos esses três elementos - o conteúdo temático, o estilo, a construção composicional estão indissoluvelmente ligados no todo do enunciado e são igualmente determinados pela especificidade de um determinado campo da comunicação. (BAKHTIN, 2003, p. 2621-262, grifo nosso)

Com base nesta linha teórica, Brait, ao tecer considerações sobre a análise/teoria dialógica do discurso proposta por Bakhtin, afirma:

$\mathrm{O}$ enfrentamento bakhtiniano da linguagem leva em conta, portanto, as particularidades discursivas que apontam para contextos mais amplos, para um extralinguístico aí incluído. [...] E mais ainda: ultrapassando a necessária análise da "materialidade linguística", reconhecer o gênero a que pertencem os textos e os gêneros que nele se articulam, descobrir a tradição das atividades em que esses discursos se inserem e, a partir desse diálogo com o objeto de análise, chegar ao inusitado de sua forma de ser discursivamente, à sua maneira de participar ativamente de esferas de produção, circulação e recepção. (BRAIT, 2006, p.13-14, grifo da autora)

Desta maneira, a perspectiva teórico-metodológica da ADD procura entender as regularidades que constituem os gêneros, objetivando compreender a relativa estabilização do gênero, procurando confirmar que "estas regularidades serão devidas não às formas fixas da língua, mas às regularidades e similaridades das relações sociais numa esfera de comunicação específica" (ROJO, 2005, p. 199).

A partir dessa abordagem pretendemos fazer uma reflexão sobre os enunciados que se constituem no gênero carta do leitor, analisando suas correlações com as esferas de atividade humana, marcadamente a esfera jornalística. O corpus selecionado é composto por 15 cartas do leitor publicadas em resposta ao artigo $^{5}$ de Lya Luft, veiculado na revista Veja edição $2316, \mathrm{n}^{\circ} 15$, de 10/04/2013, em suas versões impressa e digital, as quais serão analisadas a seguir.

\section{CONTEXTO SOCIAL DE PRODUÇÃO E CONTEÚdO TEMÁTICO}

Nosso objeto de análise são textos-enunciados do gênero carta do leitor, tendo como suporte de circulação a revista impressa e o site da revista Veja. As cartas fazem referência ao artigo de opinião intitulado "A formação de um povo", de Lya Luft (em anexo), publicado em 10/04/2013. Conforme já anunciamos, o corpus é composto por 15 cartas (em anexo), das quais 12 (numeradas de 1 a 12) circularam online, enquanto as outras 3 (numeradas de 13 a 15) circularam na revista impressa. Artigos dessa professora, jornalista e escritora são publicados quinzenalmente nesta revista e, em média, um artigo ao mês é selecionado e disponibilizado no site de Veja.

A autora apresenta linguagem coloquial e estilo marcado por suas experiências como escritora literária, sendo reconhecida por sua luta contra estereótipos sociais e pela melhoria na educação. Isto é importante que se leve em consideração, uma vez que, para buscarmos entender a natureza dos enunciados, é preciso saber como se estabelecem as relações entre locutor e interlocutor.

\footnotetext{
${ }^{5}$ Não é intenção deste artigo propor uma análise do gênero discursivo artigo de opinião, porém, considerações serão tecidas à medida que o gênero carta do leitor estabelecer relações dialógicas com o artigo.
} 
Tomando como referência o método sociológico, destacamos que se faz necessário, primeiramente, analisar o contexto social de produção e circulação, relacionando-o a seu conteúdo temático, seu estilo e sua construção composicional.

Em se tratando do contexto de produção e sua relação com o conteúdo temático, Bakhtin (2003) considera que as esferas sociais acabam por tipificar os gêneros. No mesmo sentido, Rodrigues (2001) esclarece que cada esfera conhece e aplica seus próprios gêneros. Compreendemos, assim, que cada esfera reflete e refrata aspectos relacionados à realidade. No caso do gênero carta do leitor, este estabelece relações dialógicas com aspectos relacionados à esfera jornalística, o que, de fato, determina tanto seu conteúdo temático, quanto sua constituição estilístico-composicional. Segundo Bakhtin, "a situação social mais imediata e o meio social mais amplo determinam completamente e, por assim dizer, a partir do seu próprio interior, a estrutura da enunciação" (BAKHTIN, 2012, p. 117).

Sobre o tema da enunciação, Bakhtin afirma que:

O tema da enunciação é determinado não só pelas formas linguísticas que entram na composição (as palavras, as formas morfológicas ou sintáticas, os sons, as entoações), mas igualmente pelos elementos não verbais da situação. [...] O tema da enunciação é concreto, tão concreto como o instante histórico ao qual ela pertence. Somente a enunciação tomada em toda a sua amplitude concreta, como fenômeno histórico, possui um tema. (BAKHTIN, 2012, p. 133-134)

Considerando tais afirmações, entendemos que o conteúdo temático mais relevante das cartas do leitor que compõem o corpus de análise deste estudo, geralmente remete a críticas a respeito da educação no Brasil, tendo como ponto de partida a reflexão proposta por Lya Luft em seu artigo, o qual parte de considerações gerais acerca da situação precária da educação no Brasil, para, em seguida, delimitar o tema, argumentando contrariamente ao fato de crianças poderem ser alfabetizadas até os 8 anos na escola. Esse tema, de certa forma, dialoga com outros discursos ligados à educação atualmente, tanto por parte do governo federal, que discute possibilidades de reformulações na educação, quanto por parte da iniciativa privada. Observamos, assim, um dialogismo que se estabelece com discursos advindos de contínua discussão acerca dos caminhos que devem ser tomados, em busca de uma educação de maior qualidade, tendo em vista a dos países desenvolvidos.

O artigo de Lya Luft que deu origem às cartas do corpus foi publicado na edição 2316, do dia 10 de abril de 2013(anexo 01). Na revista impressa da semana seguinte, de 17/04/2013, edição 2317, ano $46, \mathrm{n}^{\mathrm{o}} 16$, publicaram-se três cartas do leitor, enquanto no blog foram publicadas 12 cartas do leitor até o mês de outubro deste ano (anexo 02). De fato, o conteúdo temático das cartas publicadas na versão impressa da revista remete igualmente à educação no Brasil, refletindo sobre as causas da baixa qualidade do ensino no país, como podemos observar em uma das cartas, citada a seguir:

O pai que vê seu filho com dificuldades ou desleixo na escola muitas vezes faz vista grossa. Outros apelam para a imposição e até para o "castigo". Mas, enquanto o estudante não entender a importância do estudo para o próprio bem-estar futuro, ele não se dedicará. Estudantes perderam o interesse; pais deixaram de se importar; professores cansaram de insistir; e o governo, para variar, é indiferente. (Carta $\mathrm{n}^{\circ} 15$, grifos nossos) 
Cabe ressaltar que, em sua versão online ${ }^{6}$, além de fazer referências a questões relativas à educação no Brasil, tema abordado no artigo sobre o qual buscam elaborar atitude responsiva, as cartas dos leitores algumas vezes tratam de questões diversas interligadas à educação, como política, economia, ou até mesmo referências a experiências pessoais, como podemos observar a seguir:

Sou professora dos anos iniciais do ensino fundamental a 15 anos, hoje tenho 34 anos, admiro muito Lya Luft e, mais uma vez ela escreve grandes verdades reais sobre a educação brasileira, pois nesses 15 anos de sala de aula, é exatamente isso que vejo acontecer, nossos alunos cada vez aprendendo menos devido à falta de investimentos na educação. Mas sabemos muito bem porque: Povo ignorante é muito mais fácil manipular, enganar e iludir com bolsa família, paternalismo que não ensina se esforçar por um crescimento necessário. É lamentável que nossos políticos e até mesmo nosso povo nem pense no assunto! Amei sua matéria Lya, mais uma vez! (Carta $\mathrm{n}^{\mathrm{o}}$ 01, grifos nossos)

Assim, como podemos observar na parte final do texto acima, é também frequente a recorrência a uma certa entoação mais elevada, em tom de firme discordância em diversas das cartas disponibilizadas online, diferentemente do que ocorre na versão impressa, o que pode derivar do trabalho de edição por parte da revista. Importante observar que, no ambiente online não há indícios de que haja algum tipo de edição, conforme explicitado no site através de nota:

Aprovamos comentários em que o leitor expressa suas opiniões. Comentários que contenham termos vulgares e palavrões, ofensas, dados pessoais (e-mail, telefone, RG etc.) e links externos, ou que sejam ininteligíveis, serão excluídos. Erros de português não impedirão a publicação de um comentário. ${ }^{7}$

Já no caso das cartas impressas, entendemos que, por motivos de adequação ao espaço ou por direcionamento argumentativo de acordo com os interesses da revista, as cartas publicadas podem sofrer alterações, ao serem resumidas, parafraseadas. Isso nos permite afirmar que há, nesses casos, um processo de coautoria entre o autor e o editor da seção de cartas da revista.

Os exemplos selecionados apontam para o fato de que a escrita do gênero carta do leitor em ambos os suportes tem como proposta a interação entre os leitores e os articulistas, configurando-se, assim, práticas de uso da linguagem, ao atenderem necessidades específicas dos locutores como a referência a experiências pessoais relacionadas ao tema (cartas $n^{\circ} 3, n^{\circ} 9$ e $\mathrm{n}^{\mathrm{o}} 11$ ), compor críticas que contrariam as ideias presentes no artigo ao qual se referem (cartas $\mathrm{n}^{\mathrm{o}} 10$ e $\left.\mathrm{n}^{\mathrm{o}} 12\right)$, ou, ainda, tecer elogios ao estilo da autora e seu ponto de vista (cartas $\mathrm{n}^{\mathrm{o}} 3$ e $\left.\mathrm{n}^{\mathrm{o}} 13\right)$.

Na tentativa de estabelecer a interação e a relação valorativa frente ao tema, os locutores e interlocutores utilizam estratégias, valendo-se de recursos lexicais, gramaticais e

\footnotetext{
6 Todas as cartas online que compõem o corpus (01 a 13) encontram-se disponíveis em: http://veja.abril.com.br/blog/ricardo-setti/politica-cia/lya-luft-a-formacao-de-um-povo/, acesso em 03/10/2013)

${ }^{7}$ (Http://veja.abril.com.br/blog/ricardo-setti/politica-cia/lya-luft-a-formacao-de-um-povo/, Acesso em $03 / 10 / 2013)$
} 
composicionais, os quais analisamos em seguida, ao focalizarmos o estilo e a construção composicional do gênero em estudo.

\section{MARCAS ESTILÍSTICO-COMPOSICIONAIS DO GÊNERO CARTA DO LEITOR}

Para Bakhtin, "o estilo integra a unidade de gênero do enunciado como seu elemento" (BAKHTIN, 2003, p. 266). Como consequência, as especificidades de cada campo geram determinados gêneros e determinadas escolhas não somente temáticas, mas também estilísticas e composicionais. A partir do estudo de enunciados como unidades reais da comunicação discursiva, buscamos compreender de modo mais assertivo, também a natureza das unidades da língua, as quais, ao se estabelecerem dialogicamente, configuram a compreensão ativamente responsiva dos interlocutores. Concordamos com Brait (2005), no sentido de que, ao analisarmos o estilo (relacionando-o à construção composicional do gênero), estamos analisando "aspectos que, somados, contribuem para uma melhor compreensão da forma de ser da linguagem que, sendo social, histórica, cultural, deixa entrever singularidades, particularidades, sempre afetadas, alteradas, impregnadas pelas relações que a constituem" (BRAIT, 2005, p. 80).

Entendemos, ainda, que o conteúdo temático e a construção composicional estão diretamente relacionados ao estilo do gênero, uma vez que este estilo se firma com expressividade e entonação no enunciado. Nesse sentido, para Discini (2012), ao expressar a relação emotivovalorativa do locutor, sendo "resultante da apropriação feita da temática e da estrutura composicional no ato de enunciar constitutivo do gênero como enunciado concreto, tal entonação emerge como estilo" (DISCINI, 2012, p. 78).

Dessa forma, no caso das cartas do leitor selecionadas para este estudo, encontramos várias marcas estilísticas que contribuem tanto com a entonação valorativa expressa pelo conteúdo temático, como com a expressividade estilística do autor. Um exemplo disso é o emprego frequente dos pontos de exclamação e de interrogação. Além de se caracterizarem como recursos argumentativos, denotam expressividade e entonação a esses enunciados, como se pode observar em alguns dos excertos em que ocorrem, citados a seguir:

[...] Será que o ministro da Educação não fica com vergonha ao ler o artigo? E a presidente Dilma Rousseff, não fica vermelha? Uma pena o que está sendo feito com a nossa educação - cada vez pior! (Carta $n^{0} 13$, grifos nossos)

[...] É lamentável que nossos políticos e até mesmo nosso povo nem pense no assunto! Amei sua matéria Lya, mais uma vez! (Carta $\mathrm{n}^{\mathrm{o}}$ 01, grifos nossos)

[...] Caso leia, ajude-nos nessa campanha pró-professor! Obrigada e parabéns por sua coluna na VEJA e por seus livros! Adoro! (Carta $\mathrm{n}^{\mathrm{o}}$ 03, grifos nossos)

Outro recurso linguístico utilizado diz respeito ao uso predominante de linguagem coloquial, informal, em especial nas cartas disponibilizadas online, assemelhando-se, em alguns casos, a marcas próprias das cartas pessoais. A preferência, nesses casos, por períodos relativamente curtos também colabora para estabelecer uma relação de proximidade maior entre locutor e interlocutor, além de garantir um grau de informalidade aos enunciados. Isso pode ser observado, por exemplo, no texto abaixo: 
[...] No meu caso, falo por Minas Gerais, moro em Três Pontas, sul de Minas. Uma breve história pessoal: sou jornalista, professora de História, passei em primeiro lugar em concurso do Governo do Estado de Minas Gerais para exercer o cargo de professora da rede estadual. Com dois meses de trabalho, já larguei o cargo. Não aguentei a falta de respeito e disciplina por parte dos alunos, a falta de respeito e descaso dos pais para com a educação de seus filhos e por consequência, falta de respeito para com os professores de seus filhos. Além do mais, o sistema adotado em Minas, a tal progressão continuada em que o aluno NÃO PODE ser reprovado, faz do aluno um ser prepotente, que não respeita ninguém, enfim, o professor não tem autoridade nenhuma na sala, está desmoralizado. [...] (Carta $\mathrm{n}^{\circ}$ 03, grifos nossos)

Mais uma marca estilística que observamos foi em relação à identificação do sujeito-autor. Enquanto nas cartas online observamos a preferência pelo uso da primeira pessoa, nas cartas publicadas na revista em seu formato impresso, somente uma delas faz uso deste recurso. Isso nos leva a refletir sobre a possibilidade de os editores (re)organizarem as cartas e optarem pela $3^{\text {a }}$ pessoa, gerando um certo apagamento do locutor original, conforme se pode observar nas cartas $\mathrm{n}^{\circ} 13$ e $\mathrm{n}^{\circ} 15$.

Por outro lado, segundo Rodrigues (2001), é frequente o uso de índices modais em gêneros da esfera jornalística como o artigo, os quais se caracterizam como aspectos de projeção que o locutor faz da reação-resposta ativa do interlocutor. No caso da carta do leitor, não é diferente. Por meio desses recursos, observamos uma reação dialógica que se estabelece em relação ao interlocutor, buscando orientar possíveis reações-respostas, o que se pode demonstrar nas expressões destacadas nos excertos a seguir:

[...] O tema abordado é de vital importância especialmente nessa época de mudanças que estamos a vivenciar $[\ldots]$ (carta $\mathrm{n}^{\circ} 04$, grifos nossos)

[...] É preciso que compreenda que não existe liberdade sem igualdade e que a realização da maior liberdade na mais perfeita igualdade de direito e de fato, política, econômica e social ao mesmo tempo, é a justiça. (Carta $n^{\circ} 05$, grifos nossos)

Ainda tratando do estilo, ao analisarmos as cartas do leitor em sua interface no ambiente digital, identificamos o processo de intercalação desse gênero com o gênero comentário, tendo em vista a nova situação de interação na qual se configura influenciada pelo contexto de produção, o que submete esses enunciados a uma reacentuação, gerando aproximação com o gênero comentário, especialmente no que diz respeito às suas marcas estilísticocomposicionais, conforme se verifica na carta $\mathrm{n}^{\mathrm{0}} 6$ :

Penso que a hipótese mais provável é "nem pensando no assunto". É por isso que estamos quase em último lugar no ensino de matemática e ciências. No português então, melhor nem falar. (CARTA $n^{\circ} 6$, grifos nossos)

Observamos, como neste exemplo, uma tendência a uma brevidade maior nestes enunciados, além de apresentar uma linguagem mais coloquial, valendo-se de expressões popularizadas (mesmo nos enunciados maiores), o que caracteriza uma aproximação com o gênero comentário. Rodrigues (2004), ao analisar questões teóricas e metodológicas de análise de gêneros segundo a teoria bakhtiniana, explicita: 
Como os gêneros são plásticos, mais ágeis às mudanças do que as formas da língua, e apenas relativamente estáveis, eles facilmente se submetem a uma reacentuação, têm a capacidade de no seu funcionamento introduzir outros gêneros, que, nesse processo, são chamados de gêneros intercalados. [...] $\mathrm{Na}$ intercalação de gêneros, muitas vezes, estes se "alargam" por todo o enunciado que os intercalou (um romance na forma de uma carta, de diário, o poema na forma de receita culinária, o artigo jornalístico na forma de carta, os enunciados da esfera da propaganda, que "parasitam" outros gêneros e assim por diante). (RODRIGUES, 2004, p. 436, grifos nossos)

Uma vez que a carta do leitor normalmente trata de uma atitude responsiva ativa por parte dos leitores com relação a assunto da atualidade em processo de discussão, justifica-se, assim, a recorrência dos verbos no presente do indicativo por parte dos locutores, como observamos a seguir:

Não discordo do texto no que tange à qualidade da educação básica. Porém a afirmação de que a redução da qualidade do ensino superior é causada pela aceitação de alunos cotistas é preconceituosa e leviana. Lamentável uma pessoa com formação fortemente ligada à educação dizer isto. Não vejo nenhum problema do cidadão ser contrário a política de cotas, mas não aceito acusá-la do que não tem culpa. Os alunos cotistas durante o curso de formação recebem as mesmas aulas e fazem as mesmas provas que os alunos selecionados pelo processo seletivo convencional. Sou aluno cotista da UnB e posso afirmar que a responsabilidade pelo nível de ensino é da Universidade. $E$ o corpo acadêmico da instituição que define os conteúdos dos mais variados cursos. Portanto quem determina a qualidade do ensino superior são os Governantes, Professores e instituições Universitárias. [...] (Carta ${ }^{\circ} 12$, grifos nossos)

Destacamos, ainda, que o uso do pretérito perfeito é recorrente somente nos casos em que os leitores optam, em seus enunciados, por fazer referências a fatos, experiências pessoais passadas, o que ocorreu em alguns casos, como, por exemplo, na carta ${ }^{\circ} 11$ :

"Ao presenciar determinado seminário destinado aos professores, observei e realizei certas pesquisas sobre o comportamento de satisfação dos mesmos com as falas dos palestrantes [...]" (Carta $\left.n^{\circ} 11\right)$

No que se refere ainda a aspectos estilísticos dos enunciados analisados, notamos que nas cartas publicadas na revista impressa, há predominância da norma culta padrão, enquanto que nas cartas publicadas no ambiente digital, frequentemente há recorrência à ironia e ao uso de linguagem mais informal, como se torna visível nas cartas $\mathrm{n}^{\circ} 02$ e $\mathrm{n}^{\circ} 10$.

A respeito de sua construção composicional, as cartas publicadas no suporte impresso apresentam marcas da concisão, derivando textos breves e mais objetivos, o que está relacionado ao fato de que esses textos passam por uma edição prévia. Já no suporte digital, há uma variedade maior de possibilidades de constituição das cartas, que vão desde uma breve concordância com aspectos propostos por Lya Luft em seu artigo, como no exemplo da carta no03: "Penso que a hipótese mais provável é 'nem pensando no assunto'. É por isso que estamos quase em último lugar no ensino de matemática e ciências. No português então, melhor nem falar." 
Além disso, nas cartas publicadas no ambiente online, há ocorrência de enunciados mais prolongados, em que o locutor, em seu percurso de argumentação, apresenta uma retrospectiva de experiências pessoais detalhadas, ou estabelece relações com outras temáticas, como podemos observar no exemplo integralmente citado abaixo:

Adoro Lya Luft! Quando compro a revista VEJA vou direto à sua coluna. Tenho visto o empenho dessa grande escritora em escrever sobre educação, em clamar por melhorias e seriedade nesse setor, fundamental à vida das pessoas e ao crescimento de um país que queira ser verdadeiramente desenvolvido. O que venho escrever aqui é um apelo, para que profissionais assim comprometidos continuem a lutar pela educação e, se possível, sugerir a esta revista, que é tão lida e respeitada, que faça uma reportagem sobre a real situação dos professores nesse país. No meu caso, falo por Minas Gerais, moro em Três Pontas, sul de Minas. Uma breve história pessoal: sou jornalista, professora de História, passei em primeiro lugar em concurso do Governo do Estado de Minas Gerais para exercer o cargo de professora da rede estadual. Com dois meses de trabalho, já larguei o cargo. Não aguentei a falta de respeito e disciplina por parte dos alunos, a falta de respeito e descaso dos pais para com a educação de seus filhos e por consequência, falta de respeito para com os professores de seus filhos. Além do mais, o sistema adotado em Minas, a tal progressão continuada em que o aluno NÃO PODE ser reprovado, faz do aluno um ser prepotente, que não respeita ninguém, enfim, o professor não tem autoridade nenhuma na sala, está desmoralizado. Com exceção de alguns alunos que querem aprender, e que são os mais prejudicados juntamente com os professores, mais da metade dos alunos não querem fazer nada, não copiam matéria, não fazem exercícios, não obedecem o professor, vão à escola EXCLUSIVAMENTE para brincar, se divertir, farrear. E também porque são obrigados, já que o governo obriga a todas as crianças irem a escola, ficando os pais responsáveis por obrigá-los, caso contrário, respondem judicialmente.

Os professores estão sofrendo muito! Eu saí, mas e os milhares que estão lá dentro? E que escola é essa em que o aluno passa de ano infinitamente sem saber quase nada? Só a imprensa pode ajudar nessa campanha pró-educação e em SOCORRO aos professores. Por favor, nos dê voz e visibilidade! A sociedade precisa saber o que está acontecendo! Alguma coisa tem que ser feita! O professor perdeu a dignidade em seu trabalho! Está até apanhando! E mesmo que não sofra o horror da agressão física, sofre a desmoralização em sala de aula. Uma coisa absurda! Inacreditável! Eu estive lá, eu vi! Não é exagero! Esses dois meses só me renderam frustração e um problema de pressão alta, que não quer voltar ao normal, coisa que nunca tive em minha vida! Cara Lya Luft, admiro seu trabalho, sua sensibilidade. Não sei se vai chegar a ler esse desabafo/depoimento/DENUNCIA/PROTESTO. Caso leia, ajude-nos nessa campanha pró-professor! Obrigada e parabéns por sua coluna na VEJA e por seus livros! Adoro! (Carta ${ }^{\circ} 03$ )

No caso desse exemplo, em termos de construção composicional, não notamos, ao menos inicialmente, a presença de vocativos. Porém, isto ocorre em algumas das cartas de maneira muito singular (cartas $\mathrm{n}^{\circ} 8$ e $\mathrm{n}^{\circ} 9$, por exemplo). Especificamente nessas cartas, disponibilizadas no ambiente online, o locutor se dirige em seu vocativo a Ricardo Setti. Isto ocorre porque Ricardo Setti é o jornalista titular do blog em que são disponibilizados os artigos de Lya Luft $^{8}$ e os textos a eles relacionados, denominados ali como "comentários".

${ }^{8}$ http://veja.abril.com.br/blog/ricardo-setti/ 
Nesse caso, entendemos que o locutor, ao organizar seu projeto de dizer, considera tanto a colunista como sua interlocutora imediata, quanto Setti, uma vez que é em seu blog que o texto circulará. Num âmbito maior, consideramos também como interlocutores os internautas que visitam a página. Certamente isso implica, por parte do locutor das cartas, não somente em uma (re)organização da construção composicional, mas também do conteúdo temático e do estilo, aspectos imbricados, conforme já afirmado anteriormente. No caso das cartas do leitor na versão impressa da revista, não há presença de vocativos.

Quanto ao espaço em que são disponibilizadas as cartas do leitor na revista Veja, no caso da versão impressa, os textos são publicados em uma seção denominada "Leitor", disponibilizada sempre no início da revista, logo após a seção "Entrevista". Já no suporte digital, os artigos que Lya Luft escreve à revista Veja são disponibilizados no blog dirigido pelo jornalista Ricardo Setti. Nesta página, logo abaixo de cada artigo de Lya Luft, há uma seção denominada "comentários", onde se publicam os textos dos internautas que pretendem tecer considerações relacionadas ao artigo. Observamos, nesse caso, ao lado do artigo e dos "comentários", a presença de diversos recursos multimodais, como fotos, vídeos, que funcionam como hiperlinks, e que acabam por redirecionar os internautas a outros gêneros como propagandas, enquetes, notícias, reportagens. O blog funciona como uma espécie de hipergênero, ao se constituir em um gênero que abriga outros gêneros, conforme Bonini especifica:

Entendo por hipergênero os suportes de gêneros que são, ao mesmo tempo, gêneros que se compõem a partir de outros gêneros, como é o caso dos jornais, da revista, de vários tipos de home-pages (BONINI, 2003, p. 210, em nota de rodapé).

Observamos, ainda, em algumas cartas online, marcas estilístico-composicionais de finalização, despedida por parte do locutor, características do gênero, conforme constam nos exemplos $n^{0} 3$ e $n^{\circ} 8$. Além disso, as cartas dos leitores são disponibilizadas imediatamente abaixo do artigo de Lya Luft, podendo ser encaminhadas indefinidamente, o que não ocorre na revista impressa (as cartas são publicadas uma semana após a publicação do artigo, na edição seguinte). Isto confere às cartas online uma possibilidade de interação que normalmente não ocorre de outra forma. Os locutores, além disso, podem interagir mais de uma vez, assumindo atitudes responsivas diversas, tanto em relação ao artigo, quanto em relação aos outros interlocutores que participam desse processo de interação verbal.

Sobre a autoria desses enunciados, ao contrário do que ocorre na revista impressa (os autores são identificados com maior número de dados), no ambiente online, embora não seja frequente, há a possibilidade do anonimato ao locutor, como ocorre na carta $\mathrm{n}^{\circ} 5$, em que o locutor se autodenomina simplesmente "Observer". Além disso, elementos relacionados à autoria apresentam-se na composição textual da carta do leitor da seguinte maneira:

\section{Carta $\mathbf{n}^{0} 1$ : (online)}

Nome do autor, data, hora de publicação

Carta n⿳13: (impressa)

(Nome do autor, Cidade, Estado)

Enquanto nas cartas impressas há uma posição de autoria detalhada (com nome, cidade, estado), já na versão online, há tanto a possibilidade de optar por nome completo, quanto por apelidos, ou mesmo pelo anonimato, conforme citado. Aspecto recorrente nas cartas online diz respeito às marcas linguístico-composicionais que expressam a data e a hora exata de 
publicação no ambiente online, o que não ocorre na versão impressa. Isso está relacionado ao que expressa Rodrigues:

[...] Pensando-se globalmente na constituição de um jornal, pode-se mesmo propor que certos gêneros, como o artigo e o comentário, a partir da sua finalidade discursiva na comunicação jornalística e da sua concepção de autoria, funcionam, no conjunto do jornal, como a sua comissão de frente: neles é permitida uma certa "transgressão" a determinadas normas de redação impostas pelo jornal (por exemplo, o uso de palavras vetadas pelo jornal, de ironia (com cautela), de adjetivos, de marcas de primeira pessoa etc.; são textos que podem (e devem) ser assinados por seu autor). É em cima deles que o jornal constrói seu discurso de instituição que se abre para a manifestação da opinião externa ao jornal, de pluralidade ideológica [...] (RODRIGUES, 2001, p. 255, grifo da autora)

Concordamos com a autora, assim, no que se refere ao fato de que, ao considerarmos esses textos como enunciados e o gênero como tipos relativamente estáveis de enunciados, a assinatura, ao denotar aspectos da autoria, acaba por se constituir como parte do texto e do gênero, o que se mostra indispensável para sua interpretação.

\section{CONSIDERAÇÕES FINAIS}

Este artigo não pretendeu ser exaustivo nem propor análise de todas as dimensões e características do gênero carta do leitor, da esfera jornalística. Procuramos abordar apenas alguns dos aspectos relacionados ao seu conteúdo temático, estilo e construção composicional, relevantes para uma interpretação desse gênero discursivo, dentro da perspectiva da Análise Dialógica do Discurso.

Observamos que há, nessa situação social de interação verbal, mediada pelo gênero carta do leitor, especificidades tomadas pelo gênero nos diferentes suportes e mídias (impresso e online). Seu espaço de circulação abre novas possibilidades de interação, em especial no ambiente virtual, como a incorporação de outros enunciados, intercalação de gêneros, a aproximação com o gênero comentário, apontando para uma certa plasticidade, flexibilidade do gênero neste contexto. Concordamos com Rodrigues (2001), no sentido de que o processo de intercalação de gêneros "funciona como uma estratégia discursiva que possibilita ao autor se enunciar a partir de outros lugares enunciativos, dialogizando também o gênero e construindo a sua orientação axiológica" (RODRIGUES, 2001, p.247).

Nesse sentido, observamos que esses enunciados se mostram como relativamente estáveis, conforme prevê Bakhtin(2003), ou seja, esse gênero da esfera jornalística é orientado de acordo com a situação de interação, valendo-se de uma reacentuação do gênero, o que ocorre quando os internautas utilizam marcas de composição e estilo próprios do comentário ao assumirem atitude responsiva ativa ao que foi proposto pela articulista. Diferentes formas dialógicas, então, se estabelecem, de acordo com cada situação de interação.

Esta análise revelou que o corpus se constitui como reação-resposta dos leitores a posicionamentos explicitados pela escritora Lya Luft em seu artigo, relacionados a acontecimentos sociais, discussões acerca da educação na contemporaneidade. Ao estabelecer relações dialógicas com o discurso da articulista, o locutor assume posições valorativas com enunciados anteriores, se aproximando ou se afastando desses discursos, conforme prevê 
Rodrigues (2001). Isso, por conseguinte, acaba por se projetar tanto no conteúdo temático do gênero, quanto em suas marcas estilístico-composicionais.

Entendemos, assim, que o gênero carta do leitor apresenta características específicas no ambiente virtual, como consequência das transformações tecnológicas e por influência desses recursos na esfera jornalística. Esse gênero apresenta inovações em sua construção composicional e em seu estilo, além da intercalação com o gênero comentário, atendendo a novas necessidades de comunicação de sujeitos situados num tempo e espaço em constantes mudanças.

\section{REFERÊNCIAS}

ACOSTA-PEREIRA. R. O Gênero jornalístico notícia: dialogismo e valoração. Dissertação de Mestrado. PGLg.UFSC. Florianópolis, 2008.

BAKHTIN, M. Marxismo e filosofia da linguagem. São Paulo: Hucitec, 2012.

. Discurso na vida e discurso na arte (sobre a poética sociológica). Trad. de Carlos Alberto Faraco e Cristóvão Tezza [para fins didáticos]. Versão da língua inglesa de I. R.Titunik a partir do original russo, 1926. 2003.

Estética da criação verbal. Tradução de Paulo Bezerra. São Paulo: Martins Fontes,

Problemas da poética de Dostoiévski. Tradução de Paulo Bezerra. Rio de Janeiro: Forense Universitária, 2010.

BONINI, A. Midia/ suporte e hipergênero: os gêneros textuais e suas relações. RBLA, Belo Horizonte, v. 11, n.3, p. 679-704, 2011.

Os gêneros do jornal: o que aponta a literatura da área de comunicação no Brasil? Linguagem em (Dis)curso, Tubarão, v. 4, n. 1, p. 205-231, jul./dez. 2003.

BRAIT, B. Análise e Teoria do Discurso. In: BRAIT, B. Bakhtin: Outros Conceitos-chave. São Paulo: Contexto, 2006.

. (org.). Bakhtin: conceitos-chave. São Paulo: Contexto, 2005.

Bakhtin e o Círculo. São Paulo: Contexto, 2009.

. Perspectiva dialógica. In: BRAIT, Beth; SOUZA-E-SILVA, Maria Cecília (orgs). Texto ou discurso? São Paulo: Contexto, 2012.

A natureza dialógica da linguagem: formas e graus de representação dessa dimensão constitutiva. In: FARACO, Carlos Alberto; TEZZA, Cristóvão; CASTRO, Gilberto (org.). Diálogos com Bakhtin. Curitiba: Editora UFPR, 2007.

DEBRAY, R. Curso de midiologia geral. Petrópolis: Vozes, 1993.

DISCINI, N. Para o estilo de um gênero. Bakhtiniana, São Paulo, 7 (2): 75-94, Jul./Dez. 2012.

FARACO, C. A. Linguagem \& Diálogo: as ideias linguísticas do Círculo de Bakhtin. São Paulo: Parábola Editorial, 2009.

LUFT, L. A formação de um povo. Revista Veja, edição 2316, ano 46, no 15, 10/04/2013. Disponível em http://veja.abril.com.br/blog/ricardo-setti/politica-cia/lya-luft-a-formacao-deum-povo/\#comments, acesso em 30/10/2013. 
MARCUSCHI, L. A. Produção textual, análise de gêneros e compreensão. SP, Parábola Editorial, 2008.

- A questão do suporte dos gêneros textuais. Língua, linguística e literatura, João Pessoa, v. 1, n.1, p. 9-40, 2003.

MOITA LOPES, L.P. Por uma Linguística Indisciplinar. (org.) São Paulo: Parábola Editorial, 2006.

PENNYCOOK, A. Uma Linguística Aplicada transgressiva. In: MOITA LOPES, Luiz Paulo da. Por uma Linguística Aplicada indisciplinar. São Paulo: Parábola Editorial, p. 67-84, 2006.

RODRIGUES. R. H. A Constituição e Funcionamento do Gênero Jornalístico Artigo: Cronotopo e Dialogismo. Tese (Doutorado em Linguística Aplicada e Estudos da Linguagem - LAEL - PUCSP). São Paulo: PUCSP, 2001.

- Análise de Gêneros do discurso na teoria bakhtiniana: algumas questões teóricas e metodológicas. Revista Linguagem em (Dis)curso, volume 4, número 2, jan./jun. 2004.

- Os gêneros do discurso na perspectiva dialógica da linguagem: a abordagem de Bakhtin. In: MEURER, J.L; BONINI, A; MOTTA-ROTH, D. (Orgs.) Gêneros: teorias, métodos, debates. Florianópolis: Parábola, 2007.

ROJO, R. Gêneros do discurso e gêneros textuais: questões teóricas e aplicadas. In: MEURER, J.L.; BONINI, A.; MOTTA-ROTH, D. (orgs.). Gêneros: teorias, métodos e debates. São Paulo: Parábola, 2005. p. 184-207.

TÁVORA, A. D. F. Construção de um conceito de suporte: a matéria, a forma e a função interativa na atualização de gêneros textuais. Tese (Doutorado em Linguística) - Programa de Pós-Graduação em Linguística, Universidade Federal do Ceará, 2008. 
ANEXO 01

ARTIGO DE LYA LUFT: A FORMAÇÃO DE UM POVO

Revista Veja, edição 2316, ano 46, nº 15, 10/04/2013.

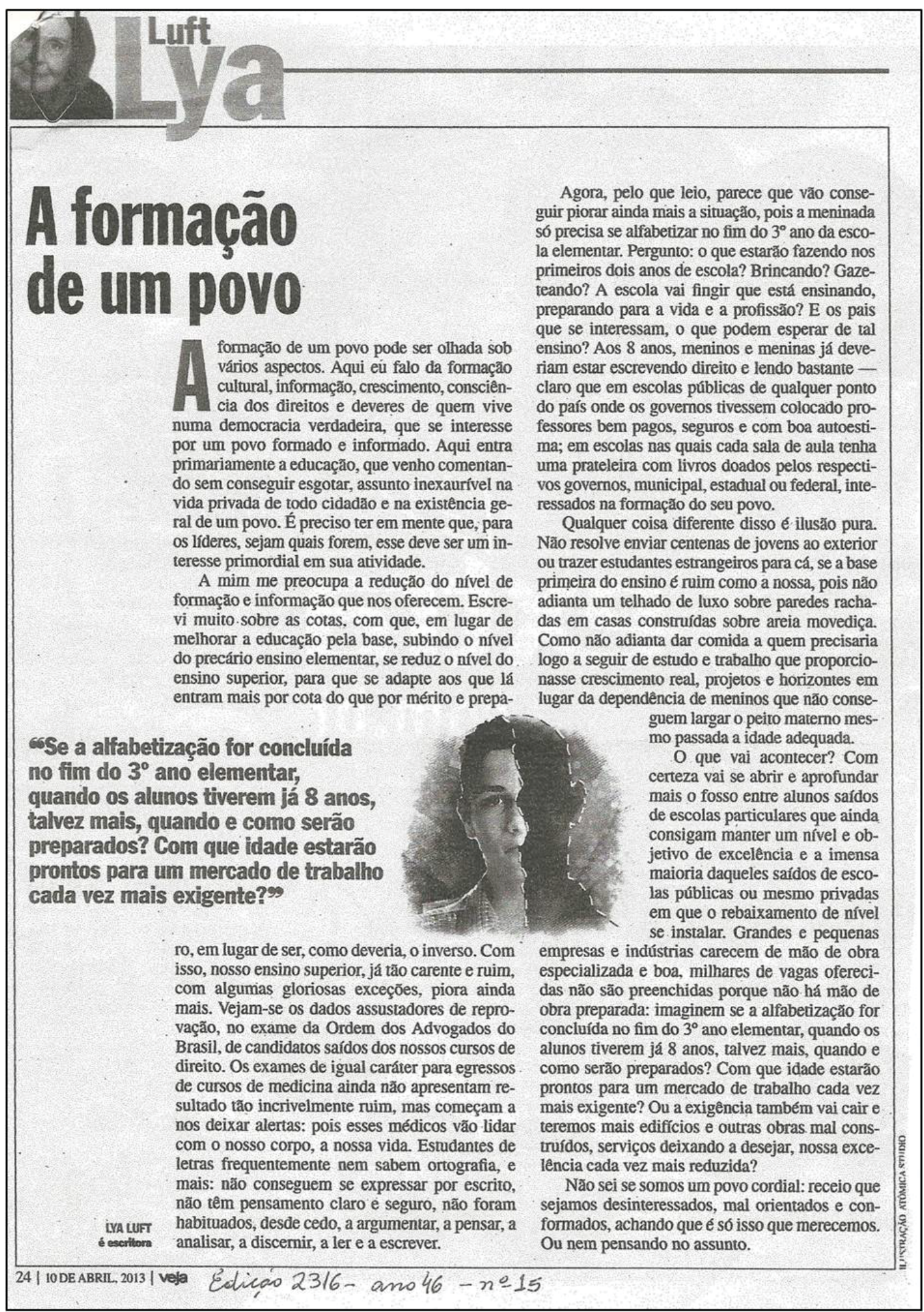




\section{ANEXO 02}

12 respostas referentes ao artigo de Lya Luft denominado $A$ formação de um povo, disponível em: http://veja.abril.com.br/blog/ricardo-setti/politica-cia/lya-luft-a-formacao-de-um-povo/\#comments , acesso em 30/10/2013.

\section{$\mathbf{N}^{0}$ 1) Edjane Silva}

30/06/2013 às 12:03

Sou professora dos anos iniciais do ensino fundamental a 15 anos, hoje tenho 34 anos, admiro muito Lya Luft e, mais uma vez ela escreve grandes verdades reais sobre a educação brasileira, pois nesses 15 anos de sala de aula, é exatamente isso que vejo acontecer, nossos alunos cada vez aprendendo menos devido à falta de investimentos na educação. Mas sabemos muito bem porque: Povo ignorante é muito mais fácil manipular, enganar e iludir com bolsa família, paternalismo que não ensina se esforçar por um crescimento necessário. É lamentável que nossos políticos e até mesmo nosso povo nem pense no assunto! Amei sua matéria Lya, mais uma vez!

\section{$\left.N^{\circ} 2\right)$ Antony de Molay}

23/04/2013 às 18:40

Olá gente de bem e progressistas (nós leitores da veja), como já havia citado em um post anterior, nunca fui um fã da colunista Lya Luft. Essa semana entretanto, qual foi minha(grata)surpresa por ler um artigo tão contundente e bem elaborado. Parabéns lya,é preciso que mais pessoas como vc que lidam com crianças, se manifestem e façam com $\mathrm{k}$ nossas vozes sejam ouvidas. É preciso acabar com a hipocrisia, um marginal juvenil é irrecuperável, ponto.tais criaturas nascem em ambientes degenerados, seu desenvolvimento é prejudicado por todos os fatores possíveis e, os estímulos que recebem são voltados para a revolta e a violência contra todos os que se colocarem em seus caminhos.li o post da professora mineira e, num breve relato ela definiu a situação em que o sistema educacional brasileiro se encontra. $\mathrm{O}$ aluno delinquente hj não é exceção e sim regra.

O pior é saber que o galã de novela mexicana, ex-ministro da educação, considera-nos vermes prenhes de falsas promessas e, defende que nesses jovens marginais se encontra o futuro do país portanto, nada de reprova-los, pois isso seria um indicador de incompetência dos administradores PTralhas em educar o povo.hj sra.lya,a juventude de baixa renda vive num caos, pais sem tempo, educação, exemplos, enfim nada para transmitir aos filhos. Indivíduos que podem eleger um político amoral,ms que é idolatrado pelos pais deste pq o mesmo lhe dá esmolas, e lhes garante impunidade.lya pergunto-lhe, já lhe passou pela mente que muitos desses canalhas esquerdistas devem ter se comemorado a morte do jovem assassinado por um celular? note que escrevo alguns, pois, não somos levianos como os esquerdistas que sem nos conhecer nos rotulam de "vermes".

somos humanos, pequenos, egoístas, pequenas matrizes individuais de conquistas e frustrações, fadados à finitude e muitas vezes à decrepitude. Entretanto precisamos que façamos ouvir nossas vozes, a marginalidade aumenta exponencialmente e, a tendência é que tudo piore pois há vinte anos atrás tudo contribuía para que nos tornássemos cidadãos de bem, hj, vemos a falência de todas as instituições que podem fazer um país andar. $\mathrm{O}$ plot do filme "idiocracy"não será a américa,já é o Brasil, infelizmente.

\section{No3) Adriana Silva Santiago}

22/04/2013 às $16: 26$

Adoro Lya Luft! Quando compro a revista VEJA vou direto à sua coluna. Tenho visto o empenho dessa grande escritora em escrever sobre educação, em clamar por melhorias e seriedade nesse setor, fundamental à vida das pessoas e ao crescimento de um país que queira ser verdadeiramente desenvolvido. O que venho escrever aqui é um apelo, para que profissionais assim comprometidos continuem a lutar pela educação e, se possível, sugerir a esta revista, que é tão lida e respeitada, que faça uma reportagem sobre a real situação dos professores nesse país. No meu caso, falo por Minas Gerais, moro em Três Pontas, sul de Minas. Uma breve história pessoal: sou jornalista, professora de História, passei em primeiro lugar em concurso do Governo do Estado de Minas Gerais para exercer o cargo de professora da rede estadual. Com dois meses de trabalho, já larguei o cargo. Não aguentei a falta de respeito e disciplina por parte dos alunos, a falta de respeito e descaso dos pais para com a educação de seus filhos e por consequência, falta de respeito para com os professores de seus filhos. Além do mais, o sistema adotado em Minas, a tal progressão continuada em que o aluno NÃO PODE ser reprovado, faz do aluno um ser prepotente, que não respeita ninguém, enfim, o professor não tem autoridade nenhuma na sala, está desmoralizado. Com exceção de alguns alunos que querem aprender, e que são os mais prejudicados juntamente com os professores, mais da metade dos alunos não querem fazer nada, não copiam matéria, não fazem exercícios, não obedecem o professor, vão à escola EXCLUSIVAMENTE para brincar, se divertir, 
farrear. E também porque são obrigados, já que o governo obriga a todas as crianças irem a escola, ficando os pais responsáveis por obrigá-los, caso contrário, respondem judicialmente. Os professores estão sofrendo muito! Eu saí, mas e os milhares que estão lá dentro? E que escola é essa em que o aluno passa de ano infinitamente sem saber quase nada?

Só a imprensa pode ajudar nessa campanha pró-educação e em SOCORRO aos professores. Por favor, nos dê voz e visibilidade! A sociedade precisa saber o que está acontecendo! Alguma coisa tem que ser feita! O professor perdeu a dignidade em seu trabalho! Está até apanhando! E mesmo que não sofra o horror da agressão física, sofre a desmoralização em sala de aula. Uma coisa absurda! Inacreditável! Eu estive lá, eu vi! Não é exagero! Esses dois meses só me renderam frustração e um problema de pressão alta, que não quer voltar ao normal, coisa que nunca tive em minha vida!

Cara Lya Luft, admiro seu trabalho, sua sensibilidade. Não sei se vai chegar a ler esse

desabafo/depoimento/DENUNCIA/PROTESTO. Caso leia, ajude-nos nessa campanha pró-professor!

Obrigada e parabéns por sua coluna na VEJA e por seus livros! Adoro!

\section{$\left.N^{\circ} 4\right)$ Antony de Molay}

$15 / 04 / 2013$ às $15: 25$

Olá, nunca fui um fã da coluna da lya luft por razões próprias. Entretanto, o tema abordado é de vital importância especialmente nessa época de mudanças que estamos a vivenciar. Divido meus afazeres em duas áreas distintas: segurança e educação. Observo em ambas as áreas uma total perversão de tudo o me foi transmitido e k akredito. enfrentamos um problema que penso ainda não ter sido percebido pelos formadores de opinião como um todo. Posso afirmar que estamos numa nau sem capitão e à iminência de um motim.vejamos:lido diariamente com profissionais sem o menor preparo para desempenhar as funções que lhes foram confiadas. Em kualker curso de licenciatura haverá a incompatibilidade entre o $\mathrm{k}$ é ensinado, o nível médio dos aprendizes e o resultado final. Não sou pesquisador e nem me interessa adentrar nessa seara, pois um dos piores males que herdamos dos portugueses, foi a mania de furar papel de modo a encher linguiça e, acho que o mercado está prenhe de tantos "intelectuais"de fim de semana.ms ao observar o quotidiano,diria que apenas $15 \%$ dos que saem de uma faculdade dominam minimamente o $\mathrm{k}$ lhes foi ministrado. Some à esse fato a degradação do núcleo familiar.hj os pais de famílias de classe média a média baixa travam batalhas diárias para a manutenção da prole que por sua vez,está irremediavelmente exposta ao que há de bom e ruim nas novas mídias maior e pior problema dessa exposição é a sexualização precoce de jovens $\mathrm{k}$ sem maturidade se engajam em relacionamentos efêmeros e geram mais crianças que fatalmente estarão à deriva.o ser humano é imitador e, observe os exemplos dos jovens hj:dj e cantores de rap e hip hop que prefiro sugerir à autora que faça sua pesquisa(comece pelo dj buru)e tire suas próprias conclusões. Não sou e hipótese alguma moralista ms a próxima novela da globo será ambientada num bordel.no ano passado quando o lixo televisivo "avenida Brasil "estava no ar vi coisas inenarráveis entre os jovens no ano k vem... para terminar,imagine na mente de um jovem assistir um programa tipo "bbb" e ver escroques que sob a égide da globo se tornam celebridades.como diria um professor meu em tom de brincadeira lógico,"estamos maus"

\section{No5) Observer}

$14 / 04 / 2013$ às 19:59

"É preciso que compreenda que não existe liberdade sem igualdade e que a realização da maior liberdade na mais perfeita igualdade de direito e de fato, política, econômica e social ao mesmo tempo, é a justiça.” Mikhail Bakunin

\section{No6) Maria Soares}

$14 / 04 / 2013$ às 19:35

Penso que a hipótese mais provável é "nem pensando no assunto". É por isso que estamos quase em último lugar no ensino de matemática e ciências. No português então, melhor nem falar.

\section{No7) Moacir}

14/04/2013 às 18:30

ERRATA17:58

Apesar de serem incapez de interpretar textos ede escrevê-los. Obridado

\section{$\left.N^{\circ} 8\right)$ Moacir}

$14 / 04 / 2013$ às $17: 58$

Setti,

Em 2012 o governo investiu R\$ 10 bilhões nas Forças Armadas.E apenas R\$ 4 bilhões em educação. Pelos números a gente percebe, claramente, que educação não é prioridade para esse governo. O que faz sentido. Sim, pois não creio que nossos governantes atuais almejem um povo educado, informado, e esclarecido. Ficaria muito 
complicado para o Governo. Por exemplo, se nosso povo soubesse o que é ajuste fiscal, o Mantega não poderia afirmar, de um lado, que medidas duras seriam tomadas nesse sentido, enquanto a Dilma preocupada com a eleição, do outro lado, aumentaria o número de Ministérios. O tal povo informado e educado saberia, é claro, que o Mantega estava falando de reduzir o custo do Estado, cortar os gastos da coisa pública, só gastar o que se arrecada. E que a Dilma ao abrir Ministérios, estava falando do oposto de tudo isso. Pois não deve sair barato criar, dar endereço, mobiliar, decorar, instalar equipamentos e contratar funciários para novos Ministérios dos quais o Brasil não precisa, só a Dilma. Em troca de votos. Uma questão de ordem eleitoreira, apenas. Então é o seguinte - perigoso esse tal de povo educado. Melhor deixar as coisas como estão. As crianças só deverão ler aos 8 anos - até lá se distrairão aprendendo a desenhar na aula de arte. Os jovens ingressarão nos cursos superiores bem "cotados", apesar nem serem incapazes de interpretar textos, nem de escrevê-los. A não ser tipo assim, enxendo de erus a fixa de redassão, enquanto passam a receita do miojo e cantam uma ode ao Palmeiras. Besteira! Quem precisa utilizar a norma culta da língua? Isso é coisa da direita. E uma vez terminados os cursos, daqui a pouco, o Olimpo dos mestrados e doutorados não será mais o reduto da excelência, mas das minorias antes oprimidas por 500 anos de história. Viva! Eu fico pensando se não seria mais fácil investir no ensino a partir do básico, ensinar a meninada a ler aos 5 anos como aconteceu comigo, e além de Português e Matemática, Geografia e História, apresentar-lhes Cidadania, Civismo, Redação e Oratória. Como acontece na maioria dos países civilizados desse mundo. Como relação ao fato, de que a tal população escolarizada, iria saber quanto seus representantes estivessem se distanciando da real, não haveria nenhum problema. A Dilma e o Mantega combinariam não mais dizer que estão para realizar - ações excludentes simultâneas. Simples assim. Brilhante o Mercadante.

Abraço

\section{No9) Bereta}

14/04/2013 às 17:30

Caro Setti. Permita-me narrar um pouco da minha história. Meus pais foram pessoas simples, sem quase nada de escolaridade. Mesmo assim, aprendi a ler jornais com o meu pai. Minha obrigação, quando menino, era ir ao correio, no interior de São Paulo. Os meios de transporte eram precários e isso fazia os jornais chegarem com até dois dias de atraso. Nem por isso ele deixou de assinar por anos seguidos a Folha de São Paulo, O Estado de São Paulo, hoje Estadão, ou a Folha da Manhã. Minha mãe, dona de casa, alfabetizou três de seus quatro filhos. A mais nova recusou-se aprender e foi albafetizada na escola. Nós, os três, tivemos a felicidade de ter nossa mãe como mestra. Passando roupa ou costurando, a cartilha estava ao seu lado e nós, a cartilha diante dos olhos. A ela não bastava nos alfabetizar. Era preciso começar a ter amor aos livros, a leitura. Lembro-me do primeiro livro que nos comprou:- No reino da bicharada. Nessa época eu não lia. Ela o fazia por mim. Depois, alfabetizado, fui para a escola. Enquanto os colegas aprendiam, eu lia Meninice, livro de um colega repetente, o Nicanor. Nunca mais o vi. Jamais perdi o gosto pela leitura. Hoje, quando vemos crianças no espaço escolar, mormente aquelas agraciadas por programas na Unicef, assistimos batuque, capoeira, mil e uma atividades grupais, mas nada de livros, matemática, ou algo que lhes possa dar alicerce intelectual. Talvez eu esteja a generalizar, mas é o que posso ver. Insisto em ver algo diferente disso, mas não me é mostrado. Logo.... Quem sabe esse novo programa governamental, esse que arrebanhará as criancinhas de quatro anos em diante, possa corrigir essa falha, pois serão no mínimo dois anos mais em recinto escolar. Talvez possa estar aí a solução. Despertar mais cedo a vontade de ler, de aprender, de participar. Aguardemos o resultado. Ele será de suma importância para os novos alunos. Para os de hoje é possível que haja maiores dificuldades.

\section{No10) Lourds}

14/04/2013 às 17:19

Parece que algum colunista não aprendeu interpretar texto. O que diz o texto da proposta de lei é justamente que todas as crianças devem estar alfabetizadas e em condições de ler plenamente ATÉ os oito anos de idade. Precisa explicar mais o que? Até sugere limite máximo de idade em que as crianças estejam alfabetizadas, assim, nos dois anos anteriores elas estarão iniciando e aperfeiçoando o que já deverá ser pleno aos oito. Puxa, que complicado, não?

\section{No11) LEANDRO}

\section{7/10/2013 às 13:35}

Ao presenciar determinado seminário destinado aos professores, observei e realizei certas pesquisas sobre o comportamento de satisfação dos mesmos com as falas dos palestrantes, e por incrível que pareça, sendo quase que ao meu ver um paradoxo, o que mais chamava a atenção eram os palavrões, os comportamentos vulgar, desprendidos pelos protagonistas das conferências. Penso eu que estamos vivendo momentos duvidosos, em um momento de descontração, um palavrão aqui, outro lá, entre poucos amigos, não é o correto, mas ainda passa, informalmente, mas num Colóquio, em que se trata sobre educação, é desproposital certas ações em que se desprestigiam convenções que foram conquistadas a partir de todo um processo histórico .Volto a repetir que tem 
atitudes que podemos até mesmo cometê-las, mas em casa em pequenos grupos, em momentos menos informal, mas não em grandes grupos, simpósios, ainda mais quando falamos em educação, quando se ministra ou fala em uma formação de professores. Pronúncias como merda, bosta, cagada, filho da puta, gestos obscenos, representação de homossexualidade banal, será mesmo necessário? creio eu que não é eu ser conservador, retrógrado, careta, mas é perceber que sem perceber a sociedade faz menção e apologia à barbárie, é retrocedermos a época dos bárbaros, em que tudo era de todos de uma forma banal, o mais forte imperava, se alimentavam com as mãos em qualquer momento, arotavam, peidavam, brigavam durante as refeições ou a qualquer momento em qualquer lugar, a promiscuidade era "aberta", se destratavam, não havia respeito, o que ocasionava brigas a todo momento. Será que eu é que estou errado nessas minhas observações?

\section{No12) LEORDO PALMEIRA}

28/08/2013 às 17:58

Não discordo do texto no que tange à qualidade da educação básica. Porém a afirmação de que a redução da qualidade do ensino superior é causada pela aceitação de alunos cotistas é preconceituosa e leviana. Lamentável uma pessoa com formação fortemente ligada à educação dizer isto. Não vejo nenhum problema do cidadão ser contrário a política de cotas, mas não aceito acusá-la do que não tem culpa. Os alunos cotistas durante o curso de formação recebem as mesmas aulas e fazem as mesmas provas que os alunos selecionados pelo processo seletivo convencional. Sou aluno cotista da UnB e posso afirmar que a responsabilidade pelo nível de ensino é da Universidade. É o corpo acadêmico da instituição que define os conteúdos dos mais variados cursos. Portanto quem determina a qualidade do ensino superior são os Governantes, Professores e instituições Universitárias. Ainda tentei pensar como a autora do texto, mas é impossível. O sistema de cotas foi implantado para tentar diminuir um prejuízo social de décadas e vejo que isso incomoda parte da classe dominante. Os (as) médicos (as), advogados (as), psicólogos (as) ... e demais categorias profissionais de prestígio querem continuar criando filhos (as) com formação similar. Entretanto os porteiros (as), vigilantes, pedreiros, empregadas domésticas não querem que os seus filhos sejam impedidos de cursar um curso superior, antes de serem recrutados pelos empregos menos qualificados ou pior, pelo mundo do crime. Igualdade na educação básica não será construída da noite pro dia e nesse sentido faço a pergunta: o enorme contingente de alunos saídos do ensino médio devem esperar a melhoria do ensino fundamental para refazê-lo, e a partir daí tentar uma vaga nas universidades?

\section{3 cartas do leitor publicadas na revista impressa, ed. 2317, ano 46, $n^{0} 16$, de 17/04/2013.}

N¹3) Em "A formação de um povo" (10 de abril), a escritora Lya Luft aborda com propriedade o maior problema do Brasil: a má qualidade do nosso ensino, em todos os níveis. Será que o ministro da Educação não fica com vergonha ao ler o artigo? E a presidente Dilma Rousseff, não fica vermelha? Uma pena o que está sendo feito com a nossa educação - cada vez pior! (Silvério José Huppes, Arroio do Meio, RS)

$\mathbf{N}^{\mathbf{0} 14}$ ) Sou professor de geografia e vou tentar mostrar aos meus alunos que nem tudo está perdido. (Renato Filgueiras de Moraes Filho, Corumbá, MS)

No15) O pai que vê seu filho com dificuldades ou desleixo na escola muitas vezes faz vista grossa. Outros apelam para a imposição e até para o "castigo". Mas, enquanto o estudante não entender a importância do estudo para o próprio bem-estar futuro, ele não se dedicará. Estudantes perderam o interesse; pais deixaram de se importar; professores cansaram de insistir; e o governo, para variar, é indiferente. (Taís Medeiros, 17 anos, Cachoeira do Sul, RS) 